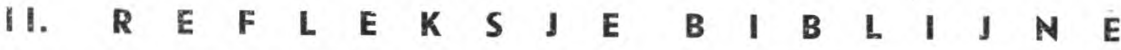

Ks. Stanistaw Grzybek, Kraków - Częstochowa

\section{KTO JEST MOIM BLIŹNIM}

\section{TEKST}

... A oto raz powstat pewien biegty $w$ Zakonie $i$ zapytał go, chcac go wystawić na próbę: „Nauczycielu, co mam czynić, aby osiagnąć żywot wieczny?. „A on zaś rzekt do niego: „Co napisane $w$ Prawdzie? Jak czytasz? A on odpowiedziat mu: „Bedziesz miłowat Pana twego, $z$ całego serca twego $i z$ całej duszy twojej $i$ ze wszystkich sit twoich $i$ ze wszystkiej myśli twojej, a bliźniego twego, jak siebie samego" (Pwt 6, 5). Odrzekł mu: „Dobrześ odpowiedziat, czyń tak, a będziesz żyt”. On zaś chciat się usprawiedliwić $i$ zapytał Jezusa: „A kto jest moim bliźnim?"' Wówczas Jezus, podejmując to pytanie, rzekt:

„Pewien czlowiek idac $z$ Jerozolimy do Jerycha wpadt między zbójców. Ci obrabowali go, pobili, a potem uciekli, pozostawiajac go na pót żywego. I zdarzyło się, że pewien kapłan zstępowat ta droga, ujrzat go $i$ minat. Podobnie $i$ lewita, nadszedt na to miejsce, a ujrzawszy go minat. Natomiast pewien Samarytanin idac ta droga ujrzat go $i$ ulitowat się nad nim. Przystąpit więc, nalat oliwy $i$ wina na rany jego $i$ obwiazat je. Potem posadzit go na swe juczne zwierzę, zawiózł go do gospody $i$ zaopiekowat się nim. Nazajutrz, wyjawszy dwa denary, dal je właścicielowi gospody, mówiac: „Zaopiekuj się nim. Jeśli zaś coś ponad to wydasz, ja, gdy będe wracat, oddam tobie. Jak ci się zdaje, który z tych trzech postapiz jak bliźni wobec człowieka, który wpadt między zbójców?" Odpowiedziat: „Ten, który okazał mu miłosierdzie”. $\mathrm{Na}$ to rzekt mu Jezus: „Idź $i$ ty czyń podobnie”.

(Ek 10, 25-37)

\section{TEO HISTORYCZNE}

Opisana wyżej rozmowa Chrystusa z uczonym w Prawie Mojżeszowym faryzeuszem miała miejsce prawdopodobnie w trzecim roku publicznej działalności Jezusa. Kontynuując swoją misyjną podróż do Galilei, przez Pereę do Judei, Jezus przybył do jednej z synagog judzkich. Tu, podczas objaśnienia prawa, wstał uczony w Piśmie i postawił Chrystusowi najbardziej wtedy dyskutowane pytanie: Co robić, aby osiagnać życie wieczne? W okresie intertestamentalnym problemy eschatologiczne były bardzo modne. Uczony faryzeusz wiele słyszał o nowym Nauczycielu z Galilei i nie tylko chciał wystawić na próbę, ale szczerze dowiedzieć się od niego całej prawdy. Był bowiem głęboko przekonany w swoim sercu, że jeśli Jezus jest naprawdę Mesjaszem - to niewątpliwie z ust jego padnie najprawdziwsza w świecie odpowiedzieć. Rozumowanie jego było słuszne.

Jezus zwyczajem semickim odpowiada na pytanie nowym pytaniem. W ten sposób przypomina swemu rozmówcy największe przykazanie, to jest tzw. modlitwę Szma Izrael, którą każdy pobożny żyd odmawiał dwa razy dziennie. Składała się ona ze słów Pwt 6, 5 i brzmiała: Słu- 
chaj Izraelu, Jahwe, Bóg twój, jest Bogiem jedynym. Będziesz miłował Pana Boga twego itd...

Modlitwa ta nie zawierała przykazania miłości bliźniego, a i prawo Mojżeszowe nigdzie tych dwóch przykazań ze sobą nie łączy. Jeśli tu występują w formie połączonej, to uczynił to na swoją rękę sam uczony żydowski, chyba w oparciu o inny tekst Kapł. 19, 18, gdzie czytamy: Nie szukaj pomsty, ani nie pamiętaj krzywdy od sąsiadów twoich. Będziesz miłowat bliźniego twego, jak siebie samego. W ten sposób sprowadził ów uczony rozmowę na właściwą, interesującą go drogę: Kto jest moim bliźnim? Zamiast odpowiedzi na to pytanie, słyszymy od Chrystusa przypowieść o Miłosiernym Samarytaninie.

Pewien człowiek wpadł między zbójców na drodze wiodącej z Jerozolimy do Jerycha. Dziś ta droga wynosi $37 \mathrm{~km}$. Dawniej była nieco krótsza, ale za to bardziej niebezpieczna. Cały czas biegnie w dól, dlatego św. Eukasz mówi, że zarówno Samarytanin, jak i kapłan i inni, którzy szli do Jerycha, musieli zstępować $w$ dót. Różnica poziomów między Jerozolimą a Jerychem wynosi około $1.000 \mathrm{~m}$. Jerycho leży bowiem $230 \mathrm{~m}$ poniżej p. $\mathrm{m}$. Od Jerozolimy dorga biegnie doliną Cedronu, u podnóża Góry Oliwnej, potem mija po lewej stronie Betanię i wypada na $8 \mathrm{~km}$ na pustą, dziką, bezludną i niebezpieczną pustynię. Przy tej drodze w licznych grotach, skałach i jarach, mieli od dawna swoje kryjówki liczni bandyci, żyjący tylko z rozboju i kradzieży. Droga ta bowiem była bardzo uczęszczana, ponieważ tędy prowadził główny szlak handlowy, zarówno $w$ kierunku na północ do Syrii i Mezopotamii, jak również i na południe, na półwysep arabski. W okresie rzymskim i bizantyjskim znajdował się na tej drodze, na $19 \mathrm{~km}$ w miejscowości Khan Hathrur silny posterunek policji, która eskortowała bogatsze karawany. Bandyci bowiem nie przebierali w swoich napadach. Atakowali zarówno bogatych kupców, jak mniejsze lub większe karawany, nie gardzili pielgrzymami, ani nawet pojedynczymi osobami, które czesto prócz odzienia i przedmiotów potrzebnych do osobistego użytku nic więcej nie mieli.

Napadnięty człowiek, o którym mówi Chrystus, należał do ludzi biednych. Ale jego ubranie też miało, dla żyjących z rozboju rabusiów jakąś wartość. Bandyci zwykle ofiar swych nie pozbawiali życia, ani ich nie ranili, gdy oni oddawali im wszystko co mieli dobrowolnie. Jeśli w naszym wypadku owego człowieka poranili i zostawili go na wpół żywego, to stało się tak dlatego, że widocznie stawiał im opór. Człowiek na Wschodzie jest bardzo przywiązany do swej własności i broni jej nieraz za ceṇ̨ własnego życia. Nie był to akt żadnej osobistej zemsty, bo nafewno zakończyłby się śmiercią napadniętego, bez tknięcia jego osobistej wiasności.

\section{EGZEGEZA FILOZOFICZNA}

Opowiadanie o Miłosiernym Samarytaninie jest przypowieścią. Przy powieść zaś jest opisem zdarzenia prawdopodobnego, które mogło, choć niekoniecznie musiało mié́ w rzeczywistości miejsce. Nie zawiera ono żadnych elementów mitycznych czy bajkowych, opisuje realnie możliwe do zaistnienia wydarzenia. Przypowieść należy do najbardziej ulubionych form nauczania Chrystusa. Podczas ostatniej Wieczerzy Chrystus sam się do tego przyznał: To wam mówiłem $w$ przypowieściach. Nadchodzi godzina, gdy już nie $w$ przypowieściach mówić im będę, ale jawnie o Ojcu oznajmię wam. (Jn 16, 25).

Zatem przypowieści o Miłosiernym Samarytaninie nie można uważaé za fikcję literacką. Takie wypadki miały bowiem miejsce za czasów Chrystusa. Prawdopodobnie Chrystus miał na myśli jakiś konkretny 
wypadek, a jeśli nie operuje tu nazwiskami, to chyba dlatego, że ten lub temu podobne wypadki były powszechnie znane wszystkim, musiał więc słyszeć o nich i nasz rozmówca z Chrystusem, uczony prawnik żydowski.

Osoby występujące w przypowieści: kapłan żydowski, Lewita, Samarytanin - to postacie najbardzíej realne. Skąd się wzięli, zwłaszcza dwaj pierwsi w drodze do Jerycha? Przypowieść sugeruje nam myśl, że pewnie po skończonej służbie w świątyni wracali do swoich domów. Jerycho było bowiem miastem kapłańskim, dlatego często tę drogę przemierzali kapłani. Nie można przypuścić żeby kapłan był jeszcze tak pogrążony $\mathrm{w}$ kontemplacji, żeby $\mathrm{mu}$ w uszach dźwięczały słowa psalmów i dlatego nie dostrzegal nawet tego, co się koło niego dzieje. Po prostu kapłani znali przykazanie miłości bliźniego (Kap. 19, 18), ale go w praktyce nie realizowali. A może ciągle jeszcze prowadzili jałowe, nic nie dające dyskusje na temat: kto jest moim bliźnim?

Trzeba szczerze powiedzieć, że w czasach Chrystusa problem ten nie był jeszcze przez wszystkich równobrzmiąco wyjaśniany. Słowo „rea” = bliźni, rozumiano różnie. Jedni sprowadzali je do grupy bardzo zamkniętej, małej i przez bliźnich rozumieli swoich krewnych, przyjaciół, członków jednej rodziny. Inni (tych była większość) przez bliźniego rozumieli człowieka, należącego do tego samego narodu, w tym wypadki do żydowskiego. Tak więc dla większości Żydów, nie-Żyd nie był bliźnim. Po tej linii rozumowania biegła egzegeza biblijnego przykazania miłości, wykładana przez wielu rabinów. Rabin Symeon ben Joc ha i nauczał: Najlepszego z goim (tj. z pogan) na karéśsierci (Melch Ex 7, 89). Od rabina Judy w traktacie Berakot 18, pochodzą słowa: Trzeba każdego dnia mówić: niech będzie błogosławiony Ten, który mnie nie uczynit poganinem.

Nic dziwnego, że taka i tym podobna interpretacja terminu ,,bliźni” mogła pomieszać pojęcia wielu nawet bardzo bogobojnych Żydów i uformować im tak sumienia, że nie odczuwali żadnej potrzeby śpieszenia z pomocą tym ludziom, którzy nie należeli do narodu żydowskiego.

Jednakże co światlejsze jednostki nie mogły pogodzić się z taką ba:dzo nacjonalistyczną interpretacją terminu ,rea”. Dlatego rabin Hille l, słynny nauczyciel św. Pawła, stawiał tezę: Miłuj każde stworzenie $i$ prowadź je do Tory, tj. do Prawa Mojżeszowego (Pirqe Abot 1, 12). A rabin M i r mówił: Nawet goj, jeśli zachowuje Tore, jest jak arcykaptan. (Sifra 86 b).

Dlatego też, wychodząc choćby już z tych kilku przykładów, nie można naszego rozmówcy z Chrystusem, uczonego Żyda posądzić o nieszczerość w stawianym pytaniu: Kto jest moim bliźnim? Jest jasne, że dla napadniętego przez zbójców Żyda, przede wszystkim z urzędu bliźnimi byli Kapłan i Lewita. Jeśli biednemu, posiniaczonemu, na wpół żywemu człowiekowi nie udzielili pomocy, świadczy to o nich bardzo ujemnie, a nawet ich bardzo obciąża. W żadnym wypadku, idąc po linii rozumowania żydowskich rabinów dla ofiary bandytów bliźnim nie był Samarytanin. A jeśli on właśnie okazał potrzebującemu miłosierdzie to co o nim sądzić? Może tė̇ czytał Torę, może znał tekst Pwt 22, 1: Gdy ujrzysz osta należcego do brata twego, albo wotu jego, które padły na drodze, nie odwrócisz się od nich, lecz nie omieszkasz im pomóc powstać. A tu na drodze leżał nie osioł ani wół, ale człowiek, którego dostrzegł drugi człowiek. Może też Samarytanin czytał księgę Tobiasza: A wszystkim, którzy postẹpuja sprawiedliwie, dawaj jałmu̇̇ne $z$ majẹtności swojej... nie odracaj twarzy od żadnego biedaka, a nie odwróci się od ciebie oblicze Boga... Jak ci tylko starczy dawaj jałmużne, tak zaskarbisz sobie wielkie dobra na dzień potrzebny (4, 7-9). 
Niewątpliwie Samarytanin dał biednemu jałmużnę. W naturze i w pieniądzach. W naturze w ten sposób, że udzielił mu pierwszej pomocy. Przedezynfekował jego rany, obandażował okaleczone miejsca, wsadził na swoje bydlę, sam może szedł obok na piechotę i przyprowadził do najbliższej gospody. Na Wschodzie gospoda (może był to właśnie ten posterunek policji) - to kawał pola, oparkaniony, tak by dzikie zwierzęta w nocy nie mogły napaść, posiadający jakiegoś stróża, który prowadził ewidencję przejeżdżających. Miał tė̇ więcej możliwości pomóc choremu, aniżeli ten kto tylko przejeżdżał tamtędy.

Samarytanin, może bogaty kupiec, okazuje się bardzo hojny. Daje nie tylko gospodarzowi gospody 2 denary, ale jeszcze pozwala mu na dodatkowe. wydatki, jeśli zajdzie tego potrzeba. W tym wszystkim kieruje się jedną intencją: zdrowiem swego przypadkowego podopiecznego. Dwa denary na owe czasy była to dość duża suma, jeśli się zważy, że dzienny zarobek robotnika wynosił jednego denara. Jakże zatem olbrzymi kontrast rysuje się pomiędzy postawą Samarytanina, a postawą dwóch przedstawicieli świątyni Jerozolimskiej. Oni wychowani na Torze, codziennie ją czytali i wiele jej tekstów znali na pamięć, ale gdy przyszlo do konkretnego powiązania przepisów Prawa Mojżeszowego z życiem nie zdali egzaminu. Może nawet przechodząc obok poranionego człowieka rzucili na niego okiem, może nawet myśleli o tym, że trzeba mu pomóc, jednak po pewnym namyśle zwyciężyły racje rozumowe: to nie jest nasz bliźni.

Zupełnie inaczej było $\mathrm{z}$ Samarytaninem. On mniej znał Pismo św., ale za to każde jego słowo cenił sobie na wage złota. Przecież to były dla niego słowa samego Boga. On raczej mniej rozumował - a więcej kochał. Dlatego św. Eukasz bardzo trafnie scharakteryzował jego sylwetkę. Samarytanin, idac ta droga, ujrzał go $i$ ulitowat się nad nim. Ponad wszelkie rozumowe racje, górę u Samarytanina wzięło miłosierdzie. I dlatego zasłużył sobie na uznanie i pochwałę samego Boga.

\section{ZNACZENIE TEOLOGICZNE}

Jaki jest sens omawianej przez nas przypowieści? Chrystus przez nią chciał uczonemu odpowiedzieć na pytanie: kto jest moim bliźnim? Ściśle mówiąc odpowiedzi na to nie dał. Uczonemu żydowskiemu chodziło tylko o teoretyczne rozstrzygnięcie problemu. Tymczasem Chrystus sprowadził całe zagadnienie na płaszczyznę praktyki.

Dlaczego tak zrobił? J. R i c ci otti ciekawie odpowiada na to: dlateno, gdyż najpiękniejsze idee pozostaja pustymi słowami, jeśli nie sa urzeczywistnione $w$ życiu (Życie Jezusa Chrystusa, Warszawa 1954, s. 459). Tu leży klucz do rozwiązania całej zagadki: Nie mędrkuj, nie filozofuj, nie uprawiaj jałowej sofistyki, ale zawsze śpiesz z pomocą, tam gdzie zachodzi paląca potrzeba udzielenia tej pomocy. Bliźnim bowiem jest każdy człowiek, nie tylko twój brat, przyjaciel, rodak, ale nawet obcokrajowiec, poganin czy bałwochwalca, wróg i nieprzyjaciel. Nịc zastanawiaj się tak, jak się kiedyś zastanawiał Sen e ka : An servus homo? (Czy też niewolnik jest czy nie jest człowiekiem?), ale raczej powtarzaj za św. Pawłem, że u Pana naszego Jezusa Chrystusa nic nie znaczy, czy ktoś jest Żydem czy nie-Żydem, Rzymianinem, czy Grekiem, znaczy tylko jedno: czy ma miłość w sercu i czy tę miłość na codzień realizuje. Nie powtarzaj za Owidiuszem: Odi profanum vulgus, (Nienawidze tego prostego pospólstwa), ale stokroć więcej niech znaczą dla ciebie słowa Chrystusa: Żal mi tego ludu!

Motorem naszego działania w stosunku do drugich niech będzie miłość. Najpierw miłość Boga, tak jak to rozumie św. Jan: Najmilsi 
miłujmy jedni drugich, bo miłość jest $z$ Boga, bo Bóg jest miłościa (Jn 4, 7,8). Potem miłość człowieka, ta prosta, szczera miłość, która na zewnątrz objawia się miłosierdziem: Wszystko co chcecie, aby wam ludzie czynili $i$ wy im czyńcie (Mt. 7, 12).

A zatem kto chce, aby inni byli dla niego bliźnimi, niech sam najpierw postępuje jak bliźni. Dewizą naszą niech będą w tym wypadku słowa Chrystusa: „Idźże i ty czyń podobnie”. Czyli w każdej okoliczności życia - bądź zawsze dla wszystkich Miłosiernym Samarytaninem. 